\title{
Nitrogen Fixing Potential of Endophytic Bacteria Isolated from Aloe barbadensis Miller and Aloe sp.
}

\author{
RAHAYU FITRIANI WANGSA PUTRIE*, TIWIT WIDOWATI, \\ SYLVIA J.R. LEKATOMPESSY, AND HARMASTINI SUKIMAN
}

\author{
Plant Symbiotic Microbes Laboratory, Research Center for Biotechnology, Indonesian Institute of Sciences (LIPI) \\ Jalan Raya Bogor KM. 46, Cibinong 16911, Indonesia
}

\begin{abstract}
Aloe is a crassulacean acid metabolism (CAM) species that are known to live in extreme enviroment such as drought condition. Nitrogen fixation procces influenced by the ability of plants to adapt in drought condition. Endophytic bacteria from Aloe and their ability for nitrogen fixation were little reported, but potential and its relationship between the ability for nitrogen fixing with resistance to drought conditions have not been reported. This research aimed study the endophytic bacteria from two varieties of aloe, namely Aloe barbadensis Miller and Aloe sp. in their ability on conducting the nitrogen fixing process and its relationship with resistance to drought. Characterization of endophytic bacteria were carried out by morphological observation of colony, Gram staining and molecular identification. Screening of nitrogen fixation was done using nitrogen-free semisolid NFb malate medium. Endophytic bacteria from Aloe sp. more than A. barbadensis in their potency of nitrogen fixation which related with habitat where their planted. A total of $40 \%$ of the endophytic bacteria isolates from the leaves of the aloe var. A. barbadensis and $62.5 \%$ of isolates from var. Aloe sp. are known to have a better ability to fixing nitrogen than the others. Isolates A. barbadensis AB 12 and Aloe sp. AS 8 were the best isolates from each varieties on ability for nitrogen fixation. Based on 16S rRNA gene analysis those two selected isolates were similar to Bacillus methalotropicus strain DA 16-5 and Bacillus aryabhattai strain B8W22.
\end{abstract}

Keyword: aloe, endophytic bacteria, nitrogen fixation

Lidah buaya merupakan salah satu spesies tanaman crassulacean acid metabolism (CAM) yang dapat hidup pada lingkungan ekstrim seperti kekeringan. Kemampuan adaptasi terhadap kekeringan dipengaruhi oleh kemampuan fiksasi nitrogen. Bakteri endofit dari lidah buaya dan kemampuannya dalam memfiksasi nitrogen telah sedikit dilaporkan, namun potensi dan hubungannya antara kemampuan fiksasi nitrogen dengan ketahanan terhadap kekeringan belum dilaporkan. Penelitian ini bertujuan untuk mengetahui dan membandingkan kemampuan bakteri endofit dari dua varietas lidah buaya, yaitu Aloe barbadensis Miller dan Aloe sp. dalam memfiksasi nitrogen serta hubungannya dengan ketahanan terhadap kekeringan. Karakterisasi bakteri endofit dilakukan dengan pengamatan morfologi koloni, pewarnaan Gram dan identifikasi molekuler. Penapisan fiksasi nitrogen dilakukan dengan menggunakan medium nitrogen-free semisolid NFb malate. Bakteri endofit yang berasal dari Aloe sp. lebih banyak yang dapat memfiksasi nitrogen dibandingkan dengan A. barbadensis dimana kemampuan ini memiliki hubungan dengan habitat tumbuhnya. Sebanyak $40 \%$ isolat bakteri endofit dari daun lidah buaya var. A. barbadensis dan sebanyak $62.5 \%$ isolat var. Aloe sp. diketahui memiliki kemampuan yang lebih dalam proses penambatan nitrogen dibandingkan dengan isolat lainnya. Isolat AB 12 dan AS 8 adalah isolat penambat nitrogen terbaik dari setiap varietas. Berdasarkan analisis gen 16S rRNA isolat tersebut mempunyai kemiripan yang tinggi dengan Bacillus methalotropicus strain DA 16-5 dan Bacillus aryabhattai strain B8W22.

Kata kunci : bakteri endofit, fiksasi nitrogen, lidah buaya

Some plant species have specific pathway which allow them to survive under extreem conditions such us drought stress. The best known is the crassulacean acid metabolism (CAM) plants, particularly the species of the genera Opuntia, Agave, and a Liliaceous species, one of them is aloe. Genus of aloe are known have around 400 species including Aloe pollyphyla, $A$. vera Linn syn. A. barbadensis Miller, A. ferox Miller, A. arborecens, A. brevifolia, A. microstigma, A. buhrii, A. hereroensis, A. humilis, A. maculata, A. chinensis

*Corresponding author; Phone: 021-8754587/8754588, Email:rahayufwputrie@gmail.com
Baker, A. indica Royle, A. perryi Baker and others (Rodriguez-Garcia et al. 2007; UCDBC 2009; Rajeswari et. al. 2012; Silva et al. 2014). Aloe is a CAM species that naturally survive to drought conditions and high temperatures. Salinity and drought stress affected to the plant height, number of leaves, leaf length, leaf thickness, aerial fresh yield, leaf fresh weight, and gel weight (Shams et al.2015).

Nitrogen fixation procces influenced by the ability of plants to adapt in drought condition (Dinh et al. 2013; Serraj 2003). Drought cause a significant decreases in nodule dry weight and amount of nitrogen fixing by the plant. Peanut genotypes that planted 
under well-watered condition and under drought stress were significantly different for nitrogen fixation. Drought tolerant genotypes had higher SPAD Chlorophyll Meter Reading (SCMR), fixed more nitrogen and achieved higher pod yield than sensitive genotypes (Dinh et al. 2013).

Biological nitrogen fixation (BNF) in agriculture are most promising on supporting the growth and productivity of plant. Plant growth promoting rhizobacteria (PGPR) had the ability to fix atmospheric nitrogen by symbiotic and non-symbiotic mechanism and provide it to plants (Saharan and Nevra 2011; Ahemad and Kibret 2014; Gupta et al. 2015). BNF were contribute $180 \times 10^{6}$ metric tons/year globally, $80 \%$ from symbiotic association and the rest from free-living or associative systems. A number of bacterial species belonging to genera of PGPR viz. Rhizobium, Bradyrhizobium, Sinorhizobium, Mesorhizobium, Azoarcus, Azotobacter, Acetobacter, Azospirillum, Burkholderia, Diazotrophicus, Enterobacter, Gluconacetobacter, Pseudomonas, and cyanobacteria (Saharan and Nevra 2011; Gupta et al. 2015). Crops inoculation by PGPR provide an integrated approach for disease management, growth promotion activity, maintain the nitogen level in agricultural soil (Ahemad and Kibret 2014; Gupta et al. 2015)

Plant-growth-promoting bacterial endophytes (PGPBEs) have been known for positively influencing plant growth in limited field conditions. Bacterial root endophytes reside in a vast number of plant species are a part of the root microbiome. Those endophyte community structure (species diversity: richness and relative abundances) were influenced by abiotic and biotic factors of environment (Gaiero et al. 2013). Nitrogen source in the atmosphere are known about $79 \%$ of the total atmospheric gases. Although nitrogen is very abundant in nature, it was often limiting plant productivity because atmospheric nitrogen is only available to organisms symbiotically associates with higher plants and non-symbiotically (Khan et al. 2008; Gulati et al. 2011; Ahemad and Kibret 2014). The abilitiy of endophytic bacteria from various plant as plant growth promoters, to fixed nitrogen and could be support in drought stress have been reported (Ngoma et al. 2013; Nogkhlaw and Joshi 2014; Ngoma et al. 2014; Miliute et al. 2015).

Exploration of endophytic bacteria from drought tolerant plant, specially leaves, stem and roots of aloe as a potential agents for antifungal activity againts Fusarium oxysporum and a vast source of extracellular enzymes such as amylase, cellulase, chitinase, pectinase, lipase, and urease also have been reported (Yadav et al. 2015). The crude and ethyl acetate fractions of the metabolites of six isolates endophytic from aloe had broad spectral antimicrobial activities against pathogenic Pseudomonas aeruginosa, Staphylococcus aureus, Bacillus cereus, Salmonella Typhimurium, Proteus vulgaris, Klebsiella pneumoniae, Escherichia coli, Streptococcus pyogenes, and Candida albicans (Akinsanya et al. 2015a).

On the other hands, the ability of endophytic bacteria from aloe as a nitrogen fixing were little reported. Investigate for endophytic bacteria assosiated with aloe from the pristine subtroprical forest in Meghalaya India, Herminiimonas saxobsidens AA JQ770186 showed that their ability for IAA production, phosphate solubilisation and nitrogen fixation which are beneficial to host plant (Nongkhlaw and Joshi 2014). Although there have been reports related to endophytic bacteria from aloe in their ability for nitrogen fixation, but potential and its relationship between the ability for nitrogen fixing with resistance to drought conditions have not been reported.

Previously, we have succeeded on isolating the culturable endophytes microbes from Aloe which could grown in Nutrien Agar (NA), Potato Dextrose Agar(PDA), and Cornmeal Malt Extract (CMM) Agar. A total of 43 isolates of endophytic microbes were isolated from the leaves of the aloe var. A. barbadensis and 28 isolates from var. Aloe sp., respectively. Endophytic microbes from $A$. barbadensis more than Aloe sp. As many as $58 \%$ microbes derived from $A$. barbadensis are bacteria, $42 \%$ fungi and Aloe sp. as many as $86 \%$ are bacteria, $14 \%$ fungi. This showed that the majority culturable endophyte symbiosis on the leaves of the aloe is a bacteria (Putrie and Sukiman 2015). Based on the case, this research aimed to study endophytic bacteria from two varieties of aloe, namely A. barbadensis and Aloe sp. and identifying isolates that are known had the best ability of of nitrogen fixation from each variety also its relationship with resistance to drought condition.

\section{MATERIALS AND METHODS}

Morphology Characteristic of Endopythic Bacteria Colony. Culturable endopytic bacteria were isolated from the leaves of the aloe var. A barbadensis and from var. Aloe sp. (Putrie and Sukiman 2015). Sample of aloe used in this research, both of them derived from an experimental garden Research Center for Biotechnology LIPI but there were differences on 
place of planted. A. barbadensis planted in pots whereas Aloe sp were planted in soil directly. Isolates were purified by streak quadrant on nutrient agar (NA) $\left(23 \mathrm{~g} \mathrm{~L}^{-1}\right)$ subsequently incubated at room temperature $24 \mathrm{~h}$ to optimize the growth of culture. Each of colony growth were observed. Those morphological were observed include colour, size, edge of the colony, the colony shape, and condition dry or slimy of colonies.

Gram Staining. Gram staining is an important and useful technique to catagorize the bacteria included in Gram-positive or Gram negative based on their morphology and differential staining properties. The method of Gram staining was described by Bartholomew (1962). The beginning stage was done by making heat-fixed smear slides of bacteria. Crystal violet as a main dye and mordant solution (Lugol's iodine) dropped for \pm 1 min, respectively. Ethanol $95 \%$ dropped until ethanol fall colored clear and not excessive (overdecolorize). Safranin as last dye dropped for $\pm 45 \mathrm{sec}$. Each after given dye, smear slides washed with distilled water, then drain flow. Gram positive bacteria stain blue-purple and Gram negative bacteria stain red.

Nitrogen Fixing Assay. Endophytic bacteria as many as 25 isolates from A. barbadensis and 24 isolates from Aloe sp. were inoculated in a nitrogenfree semisolid $\mathrm{NFb}$ malate medium $\left(\mathrm{K}_{2} \mathrm{HPO}_{4} 0.5 \mathrm{~g} \mathrm{~L}^{-1}\right.$, $\mathrm{MgSO}_{4} .7 \mathrm{H}_{2} \mathrm{O} 0.2 \mathrm{~g} \mathrm{~L}^{-1}, \mathrm{NaCl} 0.1 \mathrm{~g} \mathrm{~L}^{-1}, \mathrm{CaCl}_{2} 0.02 \mathrm{~g} \mathrm{~L}^{-1}$, trace element $2.0 \mathrm{ml} \mathrm{L}{ }^{-1}\left[\mathrm{Na}_{2} \mathrm{MoO}_{4} \cdot 2 \mathrm{H}_{2} \mathrm{O} 0.2 \mathrm{~g} \mathrm{~L}^{-1}\right.$, $\mathrm{MnSO}_{4} 0.235 \mathrm{~g} \mathrm{~L}^{-1}, \mathrm{H}_{3} \mathrm{BO}_{3} 0.2 \mathrm{~g} \mathrm{~L}^{-1}, \mathrm{CuSO}_{4} \cdot 7 \mathrm{H}_{2} \mathrm{O} 0.24$ $\mathrm{g} \mathrm{L}^{-1}$ ], bromthymol blue $0.5 \% 2.0 \mathrm{ml} \mathrm{L} \mathrm{L}^{-1}$ solution [dissolved in $0.2 \mathrm{~N} \mathrm{KOH}$ ], Fe EDTA [1.64\% solution] $4.0 \mathrm{ml} \mathrm{L}^{-1}$, and vitamin solution $1.0 \mathrm{ml} \mathrm{L}^{-1}$ [biotin $0.01 \mathrm{~g}$ $\mathrm{L}^{-1}$, pyridoxin $\left.0.02 \mathrm{~g} \mathrm{~L}^{-1}\right] \mathrm{pH}$ adjusted to 6.8 with $\mathrm{KOH}$, semi solid agar $1.75 \mathrm{~g} \mathrm{~L}^{-1}$ ) (Okon et al. 1977). This assay aimed to known ability of the isolates to fix atmospheric nitrogen in medium by stab inoculation. Incubation conducted for 3-5 d. Score positive are showed by growth of the isolates in variable depth and change in colour under the surface medium. Uninoculated $\mathrm{NFb}$ medium was kept as control on this assay (Nogkhlaw and Joshi 2014).

Identification Based on 16S rRNA Gene Analysis. The best isolates from each varieties on ability for nitrogen fixation procces subsequently molecularly identified. One colony of isolate were taken with a sterile toothpick then inserted into eppendorf tube containing $100 \mathrm{~mL} \mathrm{dH}_{2} \mathrm{O}$ subsequently it were vortex. A total of $1 \mathrm{~mL}$ suspension were used for the amplification with polymerase chain reaction
(PCR) technique. Amplification of 16S rRNA gene by PCR with primer $27 \mathrm{~F}$ (5'-AGAGTTTGATCCTGGCT CAG-3') and 1492 R (5'-GGTTACCTTGTTACGAC TT-3') (Weisburg et al. 1991) in total volume $50 \mu \mathrm{L}$. The PCR volume contains of $1 \mu \mathrm{LDNA}$ template, $2 \mu \mathrm{L}$ of primer for each forward and reverse, $25 \mu \mathrm{L}$ of $2 \mathrm{X}$ KAPA Taq Ready Mix (KAPA Biosystem) and $\mathrm{ddH}_{2} \mathrm{O}$ $20 \mu \mathrm{L}$. Amplification was performed for 30 cycles that included initial denaturation stage at a temperature 96 ${ }^{\circ} \mathrm{C}$ for $5 \mathrm{~min}$, denaturation at a temperature $96{ }^{\circ} \mathrm{C}$ for 30 sec, annealing a temperature $55^{\circ} \mathrm{C}$ for $30 \mathrm{sec}$, extension at a temperature $72{ }^{\circ} \mathrm{C}$ for $1 \mathrm{~min}$, final extension at a temperature $72{ }^{\circ} \mathrm{C}$ for $7 \mathrm{~min}$. DNA of PCR products were purified and sequenced in two directions. Sequences were analyzed by comparing the sequences with GenBank database using the Blastn (http://www.ncbi. nlm.nch.gov) programe of the National Center for Biotechnology Information to determine similarity. The length of base used for Blastn between 500-1500 bp (Clarridge 2004).

\section{RESULTS}

Endophytic bacteria, both of $A$. barbadensis and Aloe sp. were optimatelly growth on $24 \mathrm{~h}$ after incubated. Morphology of all bacteria colony from $A$. barbadensis and Aloe sp., had several similarity (Table 1, Table 2 and Fig 1). Both of them, majority of endophytic bacteria colony were pigmented, moderate, smooth of colony edge, round shape, slimy and opaque. A total of $56 \%$ isolates $\mathrm{AB}$ and $79.2 \%$ isolates AS out of each total bacterial isolates varieties were shown a slime colony, respectively. All isolates, both it from $A$. barbadensis and Aloe sp. then classified with Gram staining. Based on the result, all isolates included to Gram positive bacteria. Gram staining result showed that isolates stain blue-purple. After that, for those isolates were conducted nitrogen fixing assay used nitrogen free semisolid $\mathrm{NFb}$ malate medium. Endophytic bacteria from Aloe sp. more frequently than A. barbadensis in their potency for nitrogen fixation (Table 3). Positive results were marked by changes in media (Fig 2).

A total of $92 \%$ isolates $\mathrm{AB}$ and $96 \%$ isolates $\mathrm{AS}$ had abillity to nitrogen fixing in medium, but their ability for each isolates were different. Only $40 \%$ out of $92 \%$ isolates $\mathrm{AB}$ and $62.5 \%$ out of $96 \%$ isolates $\mathrm{AS}$. were showed a better ability to fixed nitrogen compared to the others isolates. One isolates from each varieties that shown the best ability to fixed nitrogen, $\mathrm{AB} 12$, and AS 8 subsequently indentified by 
Table 1 Morphology of endophytic bacteria from Aloe barbadensis

\begin{tabular}{|c|c|c|c|c|c|c|c|c|}
\hline \multirow{2}{*}{ No. } & \multirow{2}{*}{$\begin{array}{l}\text { Isolates } \\
\text { code }\end{array}$} & \multirow{2}{*}{$\begin{array}{l}\text { Part } \\
\text { of leaf }\end{array}$} & \multirow{2}{*}{ Pigment } & \multicolumn{5}{|c|}{ Morphological colony } \\
\hline & & & & Size & $\begin{array}{l}\text { Edge of } \\
\text { the colony }\end{array}$ & Shape & Dry/slimy & Transparantly \\
\hline 1. & $\mathrm{AB} 1$ & pole & old cream & moderate & smooth & round & dry & transpatant \\
\hline 2. & AB 2 & pole & milky white yellowish & moderate & smooth & round & slimy & opaque \\
\hline 3. & AB 3 & pole & milky white & small & smooth & round & thin slimy & opaque \\
\hline 4. & AB 4 & pole & old cream & small & smooth & round & dry & opaque \\
\hline 5. & AB 5 & pole & old cream & small & rough & round & dry & opaque \\
\hline 6. & $\mathrm{AB} 6$ & pole & old beige & moderate & smooth & round & dry & opaque \\
\hline 7. & $\mathrm{AB} 7$ & pole & $\begin{array}{l}\text { milky white yellowish } \\
\text { central part whiter }\end{array}$ & moderate & smooth & round & slimy & opaque \\
\hline 8. & AB 8 & pole & bright white milk & moderate & smooth & round & thick slimy & opaque \\
\hline 9. & AB 9 & pole & milky white yellowish & moderate & smooth & round & slimy & opaque \\
\hline 10. & $\mathrm{AB} 10$ & pole & $\begin{array}{l}\text { creamy white in the } \\
\text { middle }\end{array}$ & point & smooth & round & slimy & $\begin{array}{l}\text { transparantly } \\
\text { in the point }\end{array}$ \\
\hline 11. & AB 11 & pole & $\begin{array}{l}\text { old beige-gray (more } \\
\text { beige than } A B 6 \text { ) }\end{array}$ & moderate & smooth & round & dry & opaque \\
\hline 12. & AB 12 & pole & dull beige & moderate & smooth & round & dry & $\begin{array}{l}\text { transparantly } \\
\text { in the point }\end{array}$ \\
\hline 13. & AB 13 & pole & cream & small & smooth & round & dry & opaque \\
\hline 14. & AB 14 & pole & cream & small & smooth & round & slimy & opaque \\
\hline 15. & AB 15 & center & yellow & small & smooth & round & Thin slimy & opaque \\
\hline 16. & AB 16 & center & milky white & moderate & smooth & round & $\begin{array}{l}\text { Thick } \\
\text { slimy }\end{array}$ & opaque \\
\hline 17. & AB 17 & center & beige-gray & moderate & smooth & round & dry & opaque \\
\hline 18. & AB 18 & center & white & point & smooth & round & thin slimy & opaque \\
\hline 19. & AB 19 & center & creamy white & moderate & rough & round & thick slimy & opaque \\
\hline 20. & AB 20 & center & old beige-gray & moderate & rough & round & dry & opaque \\
\hline 21. & AB 21 & tip & white & small & smooth & oval & dry & opaque \\
\hline 22. & AB 22 & tip & white & point & smooth & round & slighty dry & transparantly \\
\hline 23. & AB 23 & tip & milky white & moderate & smooth & round & slimy & opaque \\
\hline 24. & AB 24 & tip & milky white & moderate & smooth & round & thin slimy & opaque \\
\hline 25. & AB 25 & center & yellow & point & smooth & round & slimy & opaque \\
\hline
\end{tabular}

molecular identification. Based on 16S rRNA sequence gene analysis isolat $\mathrm{AB} 12$ and $\mathrm{AS} 8$ belonged to B. methalotropicus strain DA $16-5$ and Bacillus aryabhattai strain B8W22, respectively (Table 4).

\section{DISCUSSION}

Morphology of endophytic bacteria colony showed that majority of colony from both of them are slimy. Endophytic bacteria produce more mucus or exopolisaccharide (EPS) to keep plant from water loss. Abiotic factor such as drought stress tolerance in bacteria were characterized by production of exopolysaccaride (EPS). Production of EPS were increased by bacteria during a drought as a form physiological adaptation. EPS quantity and composition were influence by genus and species of bacteria, in some cases dependent on environmental conditions for growth (Putrie et al. 2013). Based on Gram staining, all isolates from A. barbadensis and Aloe sp. were Gram positive bacteria. This was possible because adaptation of Gram positive bacteria in extreem environmet, like as drought higher than Gram negative bacteria. Gram positive bacteria could be survive in drought environment by spore. Drought periode could be promote of presence of spore forming bacteria (Meisner et al. 2015).

The ability to adapt in drought condition has been known assosiate with nitrogen fixation (Zahran 1999). Nitrogen is generally considered one of the major limiting nutrients in plant growth (Khan et al. 2008; France et al. 2009). Under drought stress, the ability to maintain high nitrogen fixation could aid peanut genotypes in maintaining high yield (Pimratch et al. 2008). Several mechanism of nitrogen fixation were involved in the physicologycal response to drought stress such as carbon shortage and nodule carbon metabolism, limitation of nitrogen and feedback 
Table 2 Morphology of endophytic bacteria from Aloe sp.

\begin{tabular}{|c|c|c|c|c|c|c|c|c|}
\hline \multirow{2}{*}{ No. } & \multirow{2}{*}{$\begin{array}{l}\text { Isolates } \\
\text { code }\end{array}$} & \multirow{2}{*}{$\begin{array}{l}\text { Part } \\
\text { of leaf }\end{array}$} & \multirow{2}{*}{ Pigment } & \multicolumn{5}{|c|}{ Morphological colony } \\
\hline & & & & Size & $\begin{array}{l}\text { Edge of } \\
\text { the colony }\end{array}$ & Shape & Dry/Slimy & Transparantly \\
\hline 1. & AS 1 & pole & yellow & moderate & smooth & round & slimy & opaque \\
\hline 2. & AS 2 & pole & cream & moderate & rough & round & slimy & opaque \\
\hline 3. & AS 3 & pole & cream & moderate & rough & round & $\begin{array}{l}\text { slimy in } \\
\text { the middle }\end{array}$ & opaque \\
\hline 4. & AS 4 & pole & $\begin{array}{l}\text { old cream of the } \\
\text { central part, light } \\
\text { cream in tip }\end{array}$ & moderate & smooth & round & $\begin{array}{l}\text { slimy in } \\
\text { the middle }\end{array}$ & $\begin{array}{l}\text { transparantly } \\
\text { in tip }\end{array}$ \\
\hline 5. & AS 5 & pole & $\begin{array}{l}\text { old cream slightly } \\
\text { yellow }\end{array}$ & moderate & smooth & round & little slime & opaque \\
\hline 6. & AS 6 & pole & old cream & moderate & smooth & round & little slime & opaque \\
\hline 7. & AS 7 & pole & $\begin{array}{l}\text { cream slightly } \\
\text { yellow }\end{array}$ & moderate & rough & round & slimy & opaque \\
\hline 8. & AS 8 & pole & $\begin{array}{l}\text { cream slightly } \\
\text { yellow }\end{array}$ & moderate & smooth & round & slimy & opaque \\
\hline 9. & AS 9 & pole & cream -gray & moderate & smooth & round & dry & opaque \\
\hline 10. & AS 10 & pole & $\begin{array}{l}\text { cream slightly } \\
\text { yellow }\end{array}$ & moderate & smooth & round & dry & opaque \\
\hline 11. & AS 11 & center & milky white & moderate & smooth & round & slimy & opaque \\
\hline 12. & AS 12 & center & cream & moderate & smooth & round & little slime & opaque \\
\hline 13. & AS 13 & center & $\begin{array}{l}\text { cream slightly } \\
\text { yellow }\end{array}$ & moderate & smooth & round & little slime & opaque \\
\hline 14. & AS 14 & center & yellow & sizeable & rough & round & little slime & opaque \\
\hline 15. & AS 15 & point & $\begin{array}{l}\text { cream slightly } \\
\text { yellow }\end{array}$ & moderate & rough & round & dry & opaque \\
\hline 16. & AS 16 & tip & $\begin{array}{l}\text { cream slightly } \\
\text { yellow }\end{array}$ & moderate & rough & round & slimy & opaque \\
\hline 17. & AS 17 & tip & milky white & moderate & rough & round & slimy & opaque \\
\hline 18. & AS 18 & tip & yellow & moderate & smooth & round & little slime & opaque \\
\hline 19. & AS 19 & tip & $\begin{array}{l}\text { cream slightly } \\
\text { yellow }\end{array}$ & moderate & rough & round & dry & opaque \\
\hline 20. & AS 20 & tip & milky white & moderate & smooth & round & slimy & opaque \\
\hline 21. & AS 21 & tip & yellow & $\begin{array}{l}\text { a little } \\
\text { small }\end{array}$ & rough & round & slimy & opaque \\
\hline 22. & AS 22 & pole & pale white & moderate & rough & round & $\begin{array}{l}\text { dry } \\
\text { wrinkled }\end{array}$ & opaque \\
\hline 23. & AS 23 & pole & bright white & moderate & smooth & round & slimy & opaque \\
\hline 24. & AS 24 & pole & white & moderate & smooth & round & slimy & opaque \\
\hline
\end{tabular}

regulation by the accumulation of nitrogen fixation products (Serraj 2013). Endophytic bacteria in plant had a metabolism that play a role in the resilience of host plants at extreme environmental conditions such as drought and influence the process of nitrogen fixation in plants. Endophytic bacteria that inhabiting on those plants had ability for fixing nitrogen by nitrogenase enzyme. Those enzyme produced by nif genes that contribute to activation of the Fe protein, iron molybdenum cofactor biosynthesis, electron donation, and regulatory genes required for the synthesis and function of the enzyme. In diazotrophs, nif genes were typically found in a cluster of around 20$24 \mathrm{~kb}$ with seven operons encoding 20 different proteins. The complex of molybdenum nitrogenase enzyme had two component proteins encoded by the nif $\mathrm{DK}$ and the $n i f \mathrm{H}$ genes. The $N i f \mathrm{DK}$ component were heterotetrameric $(\alpha 2 \beta 2)$ protein formed by two $\alpha \beta$ dimers related by a twofold symmetry. NifDK carried one iron molybdenum cofactor (FeMo-co) within the active site in each a-subunit (NifD) (Ahemad and Kibret 2014). 


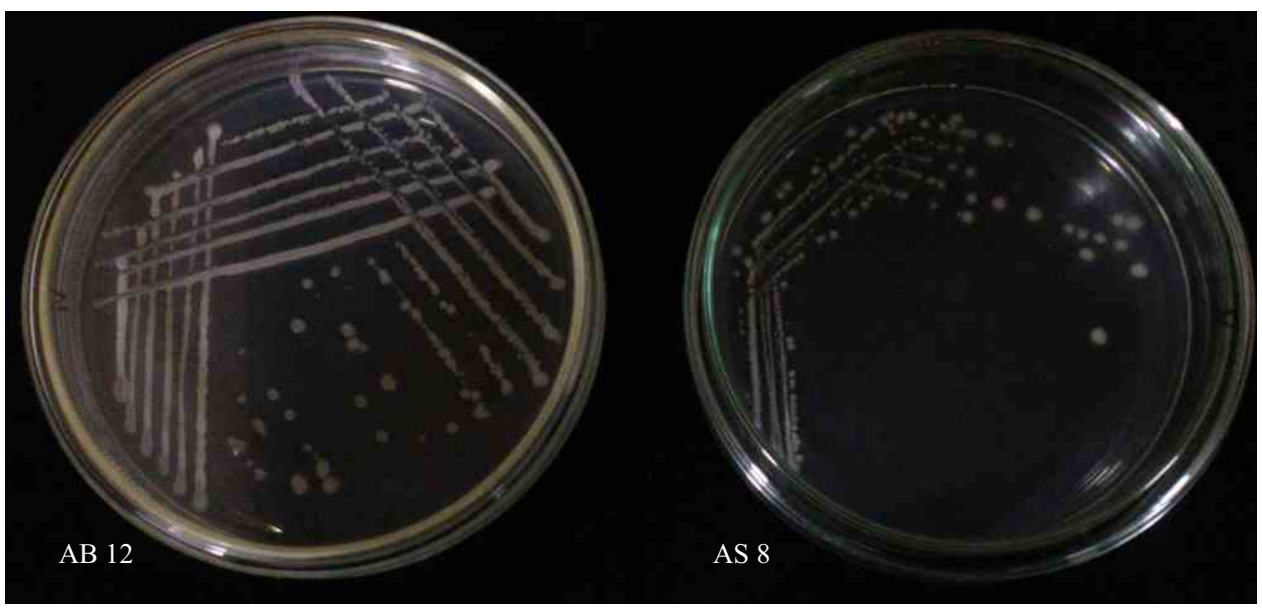

Fig 1 Morphology colony of isolates AS 8 and AB 12.

Table 3 Result of nitrogen fixing test for isolates from Aloe barbadensis and Aloe sp.

\begin{tabular}{|c|c|c|c|c|c|}
\hline No. & $\begin{array}{l}\text { Isolates from } \\
\text { A. barbadensis }\end{array}$ & Result & No. & $\begin{array}{l}\text { Isolates from } \\
\text { Aloe sp. }\end{array}$ & Result \\
\hline 1. & $\mathrm{AB} 1$ & ++ & 1. & AS 1 & ++ \\
\hline 2. & $\mathrm{AB} 2$ & ++ & 2. & AS 2 & + \\
\hline 3. & $\mathrm{AB} 3$ & ++ & 3. & AS 3 & + \\
\hline 4. & $\mathrm{AB} 4$ & + & 4. & AS 4 & - \\
\hline 5. & AB 5 & ++ & 5. & AS 5 & + \\
\hline 6. & AB 6 & + & 6. & AS 6 & ++ \\
\hline 7. & $\mathrm{AB} 7$ & + & 7. & AS 7 & ++ \\
\hline 8. & $\mathrm{AB} 8$ & ++ & 8. & AS 8 & ++ \\
\hline 9. & $\mathrm{AB} 9$ & + & 9. & AS 9 & + \\
\hline 10. & $\mathrm{AB} 10$ & + & 10 & AS 10 & ++ \\
\hline 11. & $\mathrm{AB} 11$ & - & 11. & AS 11 & ++ \\
\hline 12. & $\mathrm{AB} 12$ & ++ & 12. & AS 12 & ++ \\
\hline 13. & $\mathrm{AB} 13$ & + & 13. & AS 13 & ++ \\
\hline 14. & $\mathrm{AB} 14$ & ++ & 14. & AS 14 & ++ \\
\hline 15. & $\mathrm{AB} 15$ & + & 15. & AS 15 & ++ \\
\hline 16. & $\mathrm{AB} 16$ & ++ & 16. & AS 16 & ++ \\
\hline 17. & AB 17 & + & 17. & AS 17 & + \\
\hline 18. & $\mathrm{AB} 18$ & - & 18. & AS 18 & + \\
\hline 19. & AB 19 & ++ & 19. & AS 19 & ++ \\
\hline 20. & AB 20 & + & 20. & AS 20 & + \\
\hline 21. & AB 21 & + & 21. & AS 21 & ++ \\
\hline 22. & $\mathrm{AB} 22$ & + & 22. & AS 22 & ++ \\
\hline 23. & AB 23 & + & 23. & AS 23 & + \\
\hline 24. & AB 24 & ++ & 24. & AS 24 & ++ \\
\hline 25. & $\mathrm{AB} 25$ & + & 25. & Control & - \\
\hline 26. & Control & - & & & \\
\hline
\end{tabular}




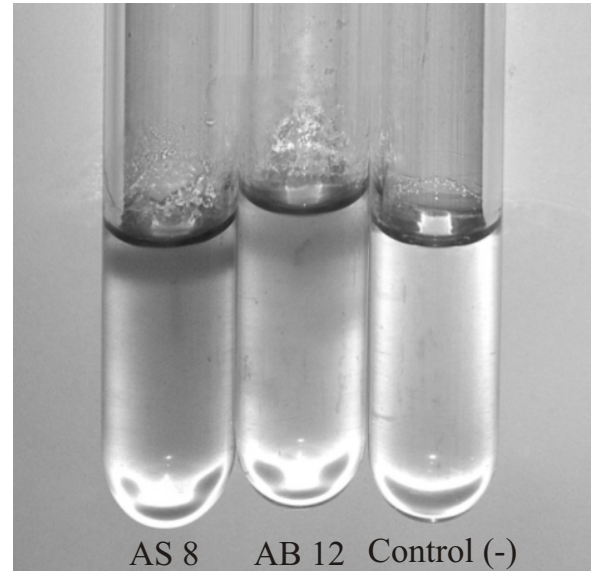

A

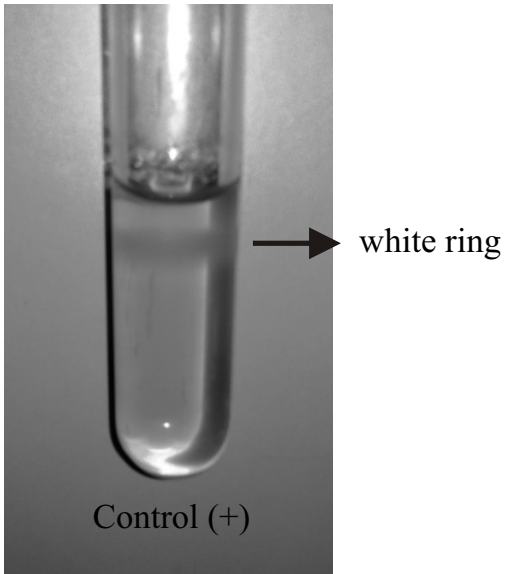

B

Fig 2 Nitrogen fixing test (A) endophytic bacteria of Aloe (B) Plant Growth Promoting Rhizobacteria (PGPR) isolate collection of Plant Symbiotic Microbes Laboratory Research Center of Biotechnology LIPI.

Table 4 Identification of AB 12 and AS 8 isolates based on 16S rRNA gene sequence homology by using BlastN program compared with Genbank sequences

\begin{tabular}{llccccc}
\hline Isolates & Species most related & Similarity & Length & Identities & Gaps & Accession number \\
\hline AB 12 & $\begin{array}{l}\text { Bacillus methalotropicus } \\
\text { strain DA 16-5 }\end{array}$ & $97 \%$ & 1437 & $193 / 199$ & $1 / 199(0 \%)$ & KU862327.1 \\
AS 8 & $\begin{array}{l}\text { Bacillus aryabhattai } \\
\text { strain B8W22 }\end{array}$ & $99 \%$ & 1533 & $1161 / 1171$ & $5 / 1171(0 \%)$ & NR. 115953.1 \\
\hline
\end{tabular}

The capability endophytic bacteria isolated from Aloe sp. to fixed nitrogen was higher than $A$. barbadensis. The high nitrogen fixing were improve the ability of adaptation to drought stress. Nitrogen fixation ability related with habitat where place of the planted. Physiological of the host plant in Rhizobiumlegume symbiosis have been known strongly impact to $\mathrm{N}_{2}$-fixing system. Symbiotic $\mathrm{N}_{2}$ fixation of legumes is also highly sensitive to soil water deficiency. Those condition promote a maximal nitrogen fixation input to the soil system by the Rhizobium-legume symbiosis (Zahran 1999).

Isolates AB 12 and AS 8 were the best isolates for nitrogen fixation procces from each varieties subsequently molecularly identified. Based on 16S rRNA gene analysis those isolates belonged to $B$. methalotropicus strain DA $16-5$ and B. aryabhattai strain B8W22. Genus of Bacillus has been known for their potency as plant growth promoters, both directly and undirectly mechanism (Putrie et al. 2013; Meldau et al. 2012; Francis et al. 2010). It was reported that Bacillus spp is one of the potential bacteria beside that could fixing nitrogen, their also could produce bioactive compound for biocontrol of numerous plant pathogenic fungi. B. methalotropicus strain BC79 were isolated from primeval forest soil in Qinling Mountains, China were able to suppress mycelial growth and conidial germination of numerous plant pathogenic fungi in dual cultures on solid media (Shan et al.2013).

This result may also confirmed and supported our finding that endophytes bacteria which was identified as Bacillus spp. have many potentials and one of them is nitrogen fixing ability. B. methylotrophicus strain L7 also known as efficient heterotrophic nitrificationaerobic denitrification (Zhang et al. 2012). Other species, B. aryabhattai strain B8W22 also known as nirogen fixing bacteria. B. aryabhattai strain B8W22 were isolated from the roots of tea (Camellia sinensis (L.) O. Kuntze) and Nicotiana attenuata are known for their potency as diazotropic bacteria in ability to fixed nitrogen and plant growth promoters (Gulati et al. 2011; Meldau et al. 2012).

The other hand, Bacillus are dominant genera of endophytic bacteria in aloe. Twenty-nine culturable bacterial endophytes were isolated from surfacesterilized root, stem and leaf tissues of $A$. vera based on molecularly characterized those belonged to 13 genera i.e. Pseudomonas, Bacillus, Enterobacter, Pantoea, Chryseobacterium, Sphingobacterium, Aeromonas, Providencia, Cedecea, Klebsiella, Cronobacter, 
Macrococcus and Shigella. The dominant genera include Bacillus (20.7\%), Pseudomonas (20.7\%), and Enterobacter (13.8\%) (Akinsanya et al. 2015a). Next generation sequencing (NGS) technology were captured effectively the metagenomics of microbiota in plant tissues and this can improve our understanding of the microbial-plant host interactions, esspesially in Aloe vera by assessing its PCR amplicon of $16 \mathrm{~S}$ rDNA sequences (V3-V4 regions). The analyses revealed Proteobacteria, Firmicutes, Actinobacteria and Bacteriodetes also known as the predominant genera (Akinsanya. et al. 2015b).

\section{ACKNOWLEDGMENTS}

Author thank and appreciate to staff of Plant Symbiotic Microbes Laboratory staff espescially, Nuriyanah, Liseu Nurjanah, and Adang Ruhiyat for all the supports given to carry out this research.

\section{REFERENCES}

Ahemad M, Kibret M. 2014. Mechanisms and applications of plant growth promoting rhizobacteria: current perspective. J King Saud Univ. 26(1):1-20. doi:10.1016/ j.jksus.2013.05.001.

Akinsanya MA, Goh JK, Lim SP, Ting ASY. 2015a. Diversity, antimicrobial and antioxidant activities of culturable bacterial endophyte communities in Aloe vera. FEMS Microbiol Lett.362(23). [on line]. doi:10.1093/femsle/fnv184.

Akinsanya MA, Goh JK, Lim SP, Ting ASY. 2015b. Metagenomics study of endophytic bacteria in Aloe vera using next-generation. Genomics Data 6:159-163. doi:10.1016/j.gdata.2015.09.0042.

Bartholomew JW. 1962. Variables influencing results, and the precise definition of steps in Gram staining as a means of standardizing the results obtained. Stain Tech. 37(3):139-155.

Clarridge JE. 2004. Impact of 16S rRNA gene sequence analysis for identification of bacteria on clinical microbiology and infectious diseases. Clin Microbiol Rev. 17(4):840-862. doi:10.1128/CMR.17.4.840862.2004 .

Dihn HT, Kaewpradit W, Jogloy S, Vorasoot N, Patanothai A. 2013. Biological nitrogen fixation of peanut genotypes with different levels of drought tolerance under mid-season drought. Sabrao J Breed Gen. 45(3):491-503.

Franche C, Lindström K, Elmerich C. 2009. Nitrogen-fixing bacteria associated with leguminous and nonleguminous plants. Plant Soil 321(1):35-59. doi:10.100 7/s11104-008-9833-8.

Francis I, Holsters, Vereecke MD. 2010. The Gram-positive side of plant-microbe interactions. Env Microbiol. 12(1):1-12. doi:10.1111/j.1462-2920.2009.01989.x

Gaiero JR, Mccall CA, thompson KA, Day NJ, Best AS, Dunfield KE. 2013. Inside the root microbiome: bacterial root endophytes and plant growth promotion. Am J Bot. 100(9):1738-1750. doi:10.3732/ajb.1200572.

Gulati A, Sood S, Rahi P, Thakur R, Chauhan S, Chawla nee Chadha I. 2011. Diversity analysis of diazotrophic bacteria associated with the roots of tea (Camellia sinensis (L.) O. Kuntze). J Microbiol Biotechnol. 21(6):545-555. doi: 10.4014/jmb.1012.12022.

Gupta G, Parihar SS, Ahirwar NK, Snehi SK, Singh V. 2015. Plant growth promoting rhizobacteria (PGPR): current and future prospects for development of sustainable agriculture. J Microb Biochem Tech. 7(2):96-102. doi:10.4172/1948-5948.1000188.

Khan Md. HR, Md. Mohiuddin Md., Rahman M. 2008. Enumeration, isolation and identification of nitrogenfixing bacterial strains at seedling stage in rhizosphere of rice grown in non-calcareous grey flood plain soil of Bangladesh. J Fac Env Scie Tech. 13(1):97-101.

Meisner A, Rousk J, Baath E. 2015. Prolonged drought changes the bacterial growth response to rewetting. Soil Biol Biochem. 88:314-322. doi:10.1016/j.soilbio. 2015.06.002.

Meldau DG, Long- HH, Baldwin IT. 2012. A native plant growth promoting bacterium, Bacillus sp. B55, rescues growth performance of an ethylene-insensitive plant genotype in nature. Front Plant Sci. 3(112) doi:10.3389/fpls.2012.00112.

Miliute I, Buzaite O, Baniulis O, Stanys V. 2015. Bacterial endophytes in agricultural crops and their role in stress tolerance: a review. Zemdirbyste-Agriculture 102(4):465478. doi:10.13080/z-a.2015.102.060.

Ngoma L, Esau B, Babalola OO. 2013. Isolation and characterization of beneficial indigenous endophytic bacteria for plant growth promoting activity in Molelwane Farm, Mafikeng, South Africa. Afr J Biotechnol. 12(26):4105-4114. doi: 10.5897/AJB2013. 12345 .

Ngoma L, Mogatlanyane K, Babalola OO. 2014. Screening of endophytic bacteria towards the development of cottage industry: an in vitro study. J Hum Ecol. 47(1):45-63.

Nongkhlaw FMW, Joshi SR. 2014. Epiphytic and endophytic bacteria that promote growth of ethnomedicinal plants in the subtropical forests of Meghalaya, India. Int J Trop Biol. 62(4):1295-1308.

Okon Y, Albrecht SL, Burris RH. 1977. Methods for growing Spirillum lipoferum and for counting it in pure culture and in association with plants. App Env Microbiol. 33(1):85-88.

Pimratch S, Jogloy S, Vorasoot N, Toomsan B, Patanothai A, Holbrook CC. 2008. Relationship between biomass production and nitrogen fixation under drought-stress conditions in peanut genotypes with different levels of drought resistance. J Agron Crop Sci. 194:15-25. doi:10.1111/j.1439-037X.2007.00286.x.

Putrie RFW, Wahyudi AT, Nawangsih AA, Husen E. 2013. 
Screening of rhizobacteria for plant growth promotion and their tolerance to drought stress. Microbiol Indones. 7(3):94-104. doi:5454/mi.7.3.2.

Putrie RFW, Sukiman H. 2015. Isolasi mikroba endofitik dari daun tanaman lidah buaya (Aloe vera (L.) Burm.f) dan uji aktivitas antimikroba [Isolation of endophytic microbes from aloe (Aloe vera (L.) Burm.f) plant leaf and antimicrobes activity assay]. In: Kusumaningrum HP, Lindayani, Nurjanah S, Rukmi MGI, Gunawan I, editors. Kontribusi Mikroba dalam Meningkatkan Kualitas Hidup Manusia. Prosiding Pertemuan Ilmiah Tahunan 2015 Perhimpunan Mikrobiologi Indonesia (PERMI); 2015 Oct. Hotel Patra Jasa Semarang. ISBN : 978-602-73556-0-6.

Rajeswari R, Umadevi M, Rahale CS, Pushpa R, Selvavenkadesh S, Kumar KPS, Bhowmik D. 2012. Aloe vera: the miracle plant its medicinal and traditional uses in India. J Pharmacog Phytochem. 1(4):118-124.

Rodriguez-Garcia R, Jasso de Rodriguez D, Gil-Marin JA, Angulo-Sanchez JL, Lira-Saldivar RH. 2007. Growth, stomatal resistance, and transpiration of Aloe vera under different soil water potentials. Ind Crop Prod. 25(2):123-128. doi:10.1016/j.indcrop.2006.08.005.

Saharan BS, Nehra V. 2011. Plant growth promoting rhizobacteria: a critical review. $L S M R-21.30 \mathrm{p}[\mathrm{on}$ line]. http://astonjournals.com/lsmr.

Serraj R. 2013. Effects of drought stress on legume symbiotic nitrogen fixation : physiological mechanism. Indian J Exp Bio. 41:1136-1141.

Shams J, Badi HN, Zeynali H, Khalighi-Sigaroodii F,Payam Najafi P. 2015. Effects of salinity and drought on morphological and chemical traits of Aloe vera plant.
Biological Forum- An Int. J 7(1):518-527.

Shan H, Zhao M, Chen D, Cheng J, Li J, Feng J, Ma J, An D. 2013. Biocontrol of rice blast by the phenaminomethylacetic acid producer of Bacillus methylotrophicus strain BC79. Crop Prot. 44:29-37. doi:10.1016/j.cropro. 2012. 10.012 .

Silva H, Sagardia S, Ortiz M, Franck N, Opazo M, Quiroz M, Baginsky C, Tapia C. 2014. Relationships between leaf anatomy, morphology, and water use efficiency in Aloe vera $(\mathrm{L})$ Burm $\mathrm{f}$. as a function of water availability. Revista Chilena de Historia Natural 87:13.doi:10.1186/ s40693-014-0013-3.

[UCDBC] University of California Davis Botanical Conservatory 2009. The genus Aloe. Botanical Notes 1(1).

Weisburg WG, Barns SM, Pelletier DA, lane DJ. 1991. 16S Ribosomal DNA amplification for phylogenetic study. J Bacteriol. 173(2):697-703.

Yadav R, Singh AV, Joshi S, Kumar M. 2015. Antifungal and enzyme activity of endophytic fungi isolated from Ocimum sanctum and Aloe vera. Afr J Microbiol Res. 9(29):1783-1788. doi: 10.5897/AJMR2015.7451.

Zahran HH. 1999. Rhizobium-legume symbiosis and nitrogen fixation under severe conditions and in an arid climate. Microbiol Mol Biol Rev. 63(4): 968-989.

Zhang QL, Liu Y, Ai GM, Miao LL, Zheng HY, Liu ZP. 2012. The characteristics of a novel heterotrophic nitrificationaerobic denitrification bacterium, Bacillus methylotrophicus strain L7. Bioresource Tech. 108:35-44. doi:10. 1016/j.biortech.2011.12.139. 